\title{
XII konferencja z cyklu: Akustyka w audiologii i foniatrii - Zjazd XX-lecia Protetyki Słuchu, 17-18 maja 2013 r., Wydział Fizyki UAM, Poznań
}

\author{
Program badań przesiewowych słuchu, \\ implanty ślimakowe, walka $\mathrm{z}$ niedosłuchem \\ w Polsce
}

Witold Szyfter

Klinika Otolaryngologii i Onkologii Laryngologicznej

Uniwersytetu Medycznego im. Karola Marcinkowskiego

w Poznaniu

Program Powszechnych Przesiewowych Badań Słuchu u Noworodków w Polsce ma już ponad 10 lat. Program ten stale dostarcza nowoczesną aparaturę diagnostyczną dla otolaryngologii, audiologii i foniatrii wartą ponad 50 mln PLN. Wywiera on ogromny wpływ na działanie logopedów, rehabilitantów słuchu, audioprotetyków. W sposób spektakularny skrócił czas wykrywania wad słuchu u dzieci w Polsce.

Program obejmuje 424 oddziały neonatologiczne na I poziomie referencyjnym, 67 oddziałów ORL, audiologicznych, placówek audiologiczno-rehabilitacyjnych na II poziomie oraz 23 ośrodki audiologiczno-rehabilitacyjne na III poziomie. Obecnie realizuje go ok. 4500 uczestników.

W okresie realizacji programu przebadano już prawie 4 mln noworodków. Do badania na II poziomie referencyjności przechodzi 6,84\% przebadanych dzieci, z uwzględnieniem dzieci, u których nie zarejestrowano otoemisji akustycznej, jak i dzieci, u których zarejestrowano otoemisję akustyczną, ale obecne były czynniki ryzyka uszkodzenia narządu słuchu. W grupie dzieci zweryfikowanych na II poziomie niedosłuch potwierdzany jest u 5,5\% dzieci. Obustronny niedosłuch czuciowo-nerwowy powyżej $70 \mathrm{~dB}$ stwierdzany jest u 0,3\%o populacji noworodków w Polsce. Program Powszechnych Przesiewowych Badań Słuchu u Noworodków w Polsce doprowadził do systematycznego zaopatrzenia dzieci w aparaty słuchowe oraz do wczesnego wszczepiania implantów ślimakowych w wieku już od 12 miesiąca życia.

\author{
Wpływ cyfrowej redukcji hałasu na \\ percepcję mowy u dzieci $\mathrm{z}$ ubytkami słuchu
}

Ewa Skrodzka

Instytut Akustyki Uniwersytetu im. Adama Mickiewicza w Poznaniu

Celem dopasowania aparatów słuchowych jest uzyskanie możliwie najbardziej naturalnego dźwięku i najlepszej zrozumiałości mowy dla każdego pacjenta i w każdych warunkach akustycznych. Jednym z czynników, który bardzo utrudnia zrozumiałość mowy, jest szum zewnętrzny nakładający się na sygnał mowy, czyli pogarszający stosunek sygnału do szumu (SNR). Wiadomo, że osoby dorosłe o słuchu prawidłowym są w stanie zrozumieć ok. 70\% wypowiedzi nawet wtedy, gdy poziom szumu jest o $6 \mathrm{~dB}$ wyższy od poziomu mowy. U prawidłowo słyszących dzieci zdolność rozumienia mowy na tle szumu zakłócającego jest gorsza niż u osób dorosłych. Zmniejszenie poziomu szumu maskującego w sygnale wyjściowym $\mathrm{z}$ aparatu słuchowego oraz ewentualne polepszenie SNR, realizowane przez układy redukcji szumu (mikrofony kierunkowe w połączeniu $\mathrm{z}$ cyfrowymi algorytmami przetwarzania dźwięku), jest korzystne dla osób dorosłych, u których problemy ze słuchem pojawiły się $\mathrm{w}$ okresie postlingwalnym. W odniesieniu do dzieci $\mathrm{z}$ problemami słuchowymi opinie o wpływie cyfrowych układów redukcji szumu są rozbieżne. W prezentacji zostaną przedstawione rezultaty badań zrozumiałości mowy dzieci w wieku 5-7 oraz 8-10 lat (czyli w wieku, w którym umiejętności językowe są jeszcze w fazie rozwoju), ze średnim (do głębokiego) ubytkiem słuchu, zaopatrzonych w aparaty słuchowe wyposażone $\mathrm{w}$ cyfrowy algorytm redukujący szum na podstawie odejmowania widmowego. 


\section{Praktyczne aspekty analizy akustycznej głosu}

\section{Bożena Wiskirska-Woźnica, Piotr Świdziński}

Katedra i Klinika Foniatrii i Audiologii Uniwersytetu

Medycznego im. K. Marcinkowskiego w Poznaniu

Analiza akustyczna głosu oceniająca wydolność głośni jako generatora akustycznego pozwala w sposób obiektywny określić funkcję fonacyjną fałdów głosowych jako źródła drgań akustycznych. Już w latach sześćdziesiątych przydatność analizy akustycznej w badaniach klinicznych podkreślał Yanagihara. Twierdził on, że podstawowym mechanizmem akustycznym odpowiedzialnym za chrypkę są tzw. perturbacje częstotliwości podstawowej, zmiany w strukturze harmonicznej sygnału oraz obecność komponentu szumowego. W badaniach własnych nie uzyskano istotnych statystycznie różnic $\mathrm{w}$ analizie parametrów MDVP między zaburzeniami organicznymi i czynnościowymi głosu. Analizując wyniki analizy akustycznej i parametrów videostroboskopii w poszczególnych grupach, stwierdzono statystycznie znamienną - korelację inną dla zaburzeń organicznych i inną dla czynnościowych. W zaburzeniach czynnościowych głosu nie znaleziono istotnych zależności między parametrami akustycznymi a stroboskopowymi, w przeciwieństwie do zaburzeń organicznych głosu, gdzie najwięcej korelacji zanotowano między amplitudą drgań i przesunięciem brzeżnym w stroboskopii a parametrami akustycznymi określającymi względną zmienność częstotliwości (Jitt, RAP, PPQ, sPPQ, vFo), zmienność amplitudy (ShimdB, Shim, APQ,sAPQ, vAM) oraz parametrami rejestrującymi nieregularności i drżenia w głosie (DUV, NUV, FTRI). Stanowi to kolejne potwierdzenie tezy, że analiza akustyczna może odgrywać ważną rolę w ocenie zaburzeń głosu jedynie w połączeniu z innymi technikami badania.

\section{Układy kompresji w aparatach słuchowych}

\section{Roman Gołębiewski}

Instytut Akustyki Uniwersytetu im. Adama Mickiewicza w Poznaniu

Jednym z podstawowych efektów niedosłuchu jest ograniczenie dynamiki słuchu (podwyższenie progu słyszalności oraz bardzo często obniżenie progu dyskomfortu).

W takim przypadku jednym z głównych zadań aparatu słuchowego jest przeniesienie i wpasowanie w dynamikę resztkową pacjenta możliwie szerokiego zakresu dynamiki sygnałów rzeczywistych. Ze względów oczywistych nie jest możliwe przeniesienie pełnego zakresu dynamiki dźwięków rzeczywistych. Z tego powodu ograniczamy się głównie do zakresu dynamiki sygnału mowy. Aby zrealizować powyższy cel, stosuje się w aparatach słuchowych tzw. układy kompresji. W referacie przedstawione i scharakteryzowane zostaną stosowane obecnie układy kompresji. Zdefiniowane zostaną podstawowe parametry układów kompresji oraz przedstawione wskazania do stosowania układów kompresji w zależności od rodzaju i wielkości niedosłuchu.
W referacie zostaną przedstawione również sytuacje, w których układy kompresji mogą być zastosowane jako skuteczne narzędzie w redukcji hałasu w aparatach słuchowych.

W ostatnich latach w aparatach słuchowych stosuje się również układy, które działają dokładnie odwrotnie do układów kompresji. Jest to tzw. ekspansja, która polega na zwiększaniu wzmocnienia ze wzrostem poziomu sygnału na wejściu aparatu słuchowego. Narzędzie to może być również stosowane jako metoda redukcji hałasu w aparatach słuchowych.

\section{Pogorszenie reakcji słuchowych u dziecka z implantem ślimakowym - możliwości postępowania}

\author{
Michał Karlik ${ }^{1}$, Olgierd Maciej Stieler ${ }^{2}$, Renata \\ Gibasiewicz ${ }^{2}$, Piotr Świdziński ${ }^{1}$ \\ ${ }^{1}$ Katedra i Klinika Foniatrii i Audiologii Uniwersytetu \\ Medycznego im. Karola Marcinkowskiego w Poznaniu \\ ${ }^{2}$ Katedra Otolaryngologii i Onkologii Laryngologicznej, \\ Uniwersytetu Medycznego im. Karola Marcinkowskiego \\ w Poznaniu
}

Implantacja ślimakowa stała się już ogólnie przyjętą metodą protezowania bardzo głębokich obustronnych ubytków słuchu. W przypadku nagłego pogorszenia się reakcji słuchowych u dziecka $\mathrm{z}$ implantem, klinicysta często stoi przed dylematem, czy do awarii doszło w części zewnętrznej, czy być może w części wewnętrznej systemu. A może to nawet pewne czynniki środowiskowe wpłynęły na pogorszenie się reakcji słuchowych dziecka?

W przypadku awarii części zewnętrznej, po naprawie serwisowej dokonuje się ponownej oceny poprawności działania systemu. Wyeliminowanie awarii części zewnętrznej stanowi już często istotny problem diagnostyczny. Do jego rozwiązania konieczna jest już wielospecjalistyczna ocena, obejmująca badanie audiologiczno-foniatryczne, laryngologiczne, akustyczne, logopedyczne, psychologiczne. Zestaw ten jest często poszerzony o kontrolę radiologiczną, ze zwróceniem szczególnej uwagi na miejsce położenia elektrody wewnątrzślimakowej. Z wykonywanych badań słuchu uwzględnia się zarówno dostosowane do wieku metody behawioralne (audiometria zabawowa, audiometria wspomagana bodźcem wzrokowym - VRA), metody obiektywne (rejestracja odruchu z mięśnia strzemiączkowego w wolnym polu słuchowym, rejestracja elektrycznie wywołanego potencjału czynnościowego nerwu słuchowego, elektrycznie wywołane potencjały słuchowe $\mathrm{z}$ pnia mózgu).

W przypadku podejrzenia awarii części wewnętrznej producent wykonuje test integralności wszczepionego urządzenia, wydając po przeanalizowaniu uzyskanych parametrów opinię, na podstawie której w ośrodku implantacyjnym podejmowana jest decyzja o ewentualnej reimplantacji. Decyzja taka jest oczywiście podejmowana w ostateczności i niezwykle rzadko. 


\section{Pomiary śródoperacyjne podczas implantacji ślimakowych - aktualny stan wiedzy}

\author{
Michał Karlik ${ }^{1}$, Olgierd Maciej Stieler², Renata \\ Gibasiewicz $^{2}$
}

\section{${ }^{1}$ Katedra i Klinika Foniatrii i Audiologii Uniwersytetu Medycznego im. Karola Marcinkowskiego w Poznaniu \\ ${ }^{2}$ Katedra Otolaryngologii i Onkologii Laryngologicznej Uniwersytetu Medycznego im. Karola Marcinkowskiego w Poznaniu}

Celem wczesnej interwencji audiologicznej jest jak najszybsze wykrycie niedosłuchu u dziecka oraz następne zaopatrzenie w aparaty słuchowe i w przypadku obustronnego głębokiego niedosłuchu, przy braku odpowiedniego zysku z protezowania tymi urządzeniami, zaimplantowanie wszczepem ślimakowym.

Ustawienie odpowiednich parametrów stymulacji elektrycznej u tak małych dzieci z implantami ślimakowymi stanowi duże wyzwanie dla osób zajmujących się tym zagadnieniem.

Przy programowaniu procesorów mowy jednymi z istotnych parametrów stymulacji są poziom wykrywania wrażenia dźwiękowego (T-level) oraz poziom maksymalnego komfortu (C-level). Z założenia, te dolne i górne poziomy stymulacji określa się przy użyciu metod behawioralnych (audiometria zabawowa, audiometria wspomagana bodźcem wzrokowym - VRA).

W przypadku dzieci słabo współpracujących, u których reakcje behawioralne sa trudne do obserwacji, wyniki pomiarów śródoperacyjnych (impedancje elektrod, elektrycznie wywołany odruch strzemiączkowy, potencjał czynnościowy nerwu słuchowego) mogą być pomocne we wstępnym ustawieniu parametrów stymulacji elektrycznej.

W poszczególnych ośrodkach implantacyjnych dokonuje się różnych analiz i porównań, zarówno w progu elektrycznie wywołanego odruchu z mięśnia strzemiączkowego z poziomami maksymalnego komfortowego słyszenia, jak i elektrycznie wywołanego potencjału czynnościowego nerwu słuchowego z poziomami odczucia wrażenia dźwiękowego.

Autorzy, w oparciu o 19-letnie doświadczenie, przedstawiają własne stanowisko zarówno w sprawie wykorzystania metod obiektywnych w ustawianiu parametrów stymulacji elektrycznej, jak i w sprawie automatyzowania pomiarów śródoperacyjnych.

\section{Pomiar aparatu słuchowego z wykorzystaniem sygnału mowopodobnego ISTS}

\section{Edyta Bogusz}

Instytut Akustyki Uniwersytetu im. Adama Mickiewicza w Poznaniu

Celem stosowania aparatów słuchowych jest skompensowanie ubytku słuchu poprzez przywrócenie prawidłowej percepcji dźwięków, a przede wszystkim zapewnienie możliwie najlepszej zrozumiałości mowy. Obowiązujące do niedawna standardy pomiarowe IEC 60118-1983/94 i ANSI 3.22-2003/07 zostały opracowane dla liniowych aparatów analogowych. Na podstawie ww. standardów trudno jest określić, jak sygnał mowy będzie przetwarzany w rzeczywistych warunkach pracy aparatu słuchowego, ponieważ standardy te:

1) Wykorzystują jako sygnał testowy sygnał tonalny lub niezmodulowany sygnał szumowy.

2) Wymagają ustawienia wzmocnienia aparatu słuchowego na maksimum lub określonego ustawienia testowego.

3) Wymagają wyłączenia dodatkowych układów adaptacyjnych, m.in.. układu redukcji szumu, eliminacji sprzężenia zwrotnego, eliminacji echa.

Z ww. powodów w 2004 roku European Hearing Instrument Manufacturers Association (EHIMA) rozpoczęła realizację projektu ISMADHA (International Standard for Measurement of Advances Digital Hearing Aids), którego wynikiem jest określenie nowych standardów, opisanych w normie IEC 60118-15: 2012. Standardy te umożliwiają:

1) Użycie docelowych ustawień aparatów słuchowych, tj. 1.1) Aparat słuchowy jest mierzony po wstępnym dopasowaniu do ubytku słuchu pacjenta.

1.2) Włączone są dodatkowe adaptacyjne algorytmy przetwarzania sygnału.

2) Zastosowanie międzynarodowego testowego sygnału symulujacego mowę i posiadającego najważniejsze cechy mowy ISTS (International Speech Test Signal).

Sygnał ISTS powstał na bazie rzeczywistych nagrań mowy kobiet oraz 6 języków: angielski amerykański, arabski, chiński, hiszpański, niemiecki i francuski.

Pomiar wstępnie dopasowanego aparatu słuchowego odbywa się $\mathrm{z}$ wykorzystaniem analizy percentylnej sygnału ISTS. Analiza percentylna przeprowadzana jest w pasmach tercjowych o częstotliwościach środkowych od $250 \mathrm{~Hz}$ do $6300 \mathrm{~Hz}$, dla krótkich segmentów sygnału ISTS trwających $125 \mathrm{~ms} \mathrm{z}$ zastosowaniem 50\% overlapingiem. Na aparat słuchowy podawany jest sygnał ISTS ( $1 \mathrm{~min}$ ) o średnim poziomie prezentacji $65 \mathrm{~dB}$ SPL (również zalecane są poziomy 55 i $80 \mathrm{~dB}$ SPL). Analizowane jest ostatnie 45 s sygnału. Obliczany jest poziom wyjściowy oraz wzmocnienie wprowadzane przez aparat słuchowy dla segmentów odpowiadających percentylowi 30. (mowa cicha), 65. (mowa średnio głośna) i 99. (mowa głośna). Dodatkowo obliczany jest średni poziom wyjściowy oraz wzmocnienie z całego czasu analizy (45 s) sygnału ISTS. Zastosowanie analizy percentylnej umożliwia bezpośrednie pokazanie działania 
algorytmów dynamicznej kompresji. Programując aparat słuchowy, dąży się do tego, by percentyl 30. znalazł się powyżej progu słyszalności pacjenta, percentyl 99. poniżej lub w pobliżu UCL, a percentyl 65. w środkowym zakresie obszaru słyszalności pacjenta.

\section{Skryning słuchowy noworodków - follow up}

\section{Alicja Sekula}

Katedra i Klinika Foniatrii i Audiologii Uniwersytetu Medycznego im. K. Marcinkowskiego w Poznaniu

W Klinice Foniatrii i Audiologii jako ośrodku prowadzącym program badań przesiewowych słuchu noworodków na poziomie II oraz III sprawuje się opiekę specjalistyczną nad dziećmi, u których rozpoznano niedosłuch, oraz nad dziećmi z czynnikami ryzyka, u których nie potwierdzono podejrzenia niedosłuchu, lecz z powodu możliwości ich negatywnego wpływu na dalszy rozwój komunikatywny wykonuje się planowe kontrole specjalistyczne.

Materiał obejmuje następujące grupy badawcze:

1) Niedosłuch odbiorczy

a) obustronny

2) Niedosłuch przewodzeniowy

a) fluktuacyjny

b) w zespołach wad wrodzonych

3) Niedosłuch mieszany

4) Czynniki ryzyka uszkodzenia słuchu

a) podejrzenie uwarunkowania genetycznego

b) $\mathrm{TORCH}$

c) czynniki ryzyka neuropatii słuchowej

d) zespół czynników okołoporodowych

5) Dzieci kwalifikowane do implantacji ślimakowej.

Metodyka: Badania słuchu wykonywane są w ramach hospitalizacji lub opieki ambulatoryjnej. Dobór obiektywnej metody diagnostycznej uzależniony jest od rozpoznawanego stanu klinicznego. Badanie uzupełniane jest metodą behawioralną, dostosowaną do wieku i rozwoju dziecka. Specjalistyczna ocena pedoaudiologiczna obejmuje ustalenie etapu rozwoju komunikatywnego. Stosownie do potrzeb, kwalifikuje się dziecko do szczegółowej oceny psychologicznej oraz logopedycznej.

Uzyskane wyniki badań pozwalają na indywidualne ukierunkowanie procesu leczniczego i rehabilitacyjnego z optymalną efektywnością.

\section{Ocena poprawy artykulacji u dorosłych pacjentów po założeniu wszczepu ślimakowego}

\author{
Anna Żebryk-Stopa, Michał Karlik, Bożena \\ Wiskirska-Woźnica
}

Katedra i Klinika Foniatrii i Audiologii Uniwersytetu
Medycznego im. Karola Marcinkowskiego w Poznaniu

Zaburzenia mowy spowodowane głębokim obustronnym niedosłuchem odbiorczym dotyczą zarówno oddychania, fonacji, jak i artykulacji. Oddychanie cechuje się krótkimi i głębokimi wdechami, skróceniem fazy wydechowej, brakiem synchronizacji z fonacją i artykulacją, co prowadzi do nieprawidłowego (skróconego lub przedłużonego) wymawiania poszczególnych głosek. W zaburzeniach artykulacji zwraca się uwagę na znacznie większe zniekształcenia samogłosek „e, i” (dominacja wyższych częstotliwości) w stosunku do samogłosek „a, o, u” (niskie częstotliwości). Dochodzi do zniekształcenia większości spółgłosek, a zwłaszcza tych wysokoczęstotliwościowych „s, z, c, sz, rz, cz, ś, ź, ć, dz, dź”, zamiany spółgłosek, np. „k” na „t”.

Zaprotezowanie słuchowe poprzez zastosowanie implantu ślimakowego daje możliwość poprawy artykulacji dzięki zwrotnej kontroli słuchowej wypowiadanych głosek. Jest to najbardziej wyraźne właśnie w zakresie wysokich częstotliwości. Stopień poprawy artykulacji zależy od rodzaju głuchoty (prelingwalna, postlingwalna, niedosłuch postępujący), jak i czasu rehabilitacji.

Autorzy przedstawiają własne doświadczenia, porównując ocenę artykulacji dokonaną w okresie kwalifikacji do implantu (przed zaprotezowaniem wszczepem ślimakowym) $\mathrm{z}$ oceną dokonaną po kilku miesiącach lub latach korzystania z wszczepialnej protezy słuchu.

\section{Rola emocji w kontaktach $\mathrm{z}$ pacjentem}

\section{Agnieszka Ruta}

Uniwersytet Ekonomiczny w Poznaniu

Emocje odgrywają ogromną rolę w życiu każdego człowieka, zarówno zawodowym jak i prywatnym. Do niedawna uważano, że w kontaktach biznesowych nie należy ich ujawniać. Jednak liczne badania wskazują, że emocje kształtują ludzkie preferencje i zachowania nabywcze, a ukrywanie ich jest często przyczyną agresji. Specjaliści wskazują, że pomimo wielu przeprowadzonych badań, emocje są wciąż niedoceniane we współczesnych teoriach organizacji. Natomiast ostatnie prace z zakresu psychologii podkreślają, że odpowiednie zarządzanie emocjami pacjentów stanowi kluczowy warunek sukcesu placówki medycznej. W związku z powyższym rodzi się pytanie, jakie emocje i w jakim stopniu wpływają na podejmowane przez pacjentów decyzje oraz czy ich znajomość może wpłynąć na jakość kontaktów i wyniki sprzedażowe. Prowadzone w ostatnich latach badania nad emocjami w organizacjach ukazują ich olbrzymi potencjał, zwłaszcza kiedy dostrzeże się możliwość praktycznego zastosowania wiedzy 
o emocjach do zarządzania działami obsługi. Uwzględnienie emocji w znaczny sposób wpływa na zrozumienie zachowań konsumentów i ich decyzje. Zwrócenie uwagi na emocje odkryło m.in. potrzebę współgrania między emocjami klienta i pracownika, tzw. zjawisko „zarażania się” emocjami (Hatfield, Caccioppo, 1994). Psychologia dostarcza dowodów na to, że emocjami pacjentów można zarządzać, i wskazuje, w jaki sposób to robić. Ludzie, którzy biorą udział w procesie świadczenia usług, powinni zwrócić szczególną uwagę na czynniki kształtujące wrażenia i doznania klienta. Połączenie wiedzy z zakresu psychologii behawioralnej z teoriami zarządzania relacjami klientów jest w stanie efektywnie poprawić jakość świadczonych usług gabinetów i wykreować pożądane doznania w kontaktach z pacjentem.

\section{Przydatność badań otoemisji akustycznej $\mathrm{w}$ diagnostyce audiologicznej}

\section{Barbara Maciejewska ${ }^{1}$, Antoni Pruszewicz ${ }^{1}$, Bożena Wiskirska-Woźnica', Anna Hashimoto ${ }^{1}$, Piotr Świdziński ${ }^{1}$, Michał Michalak ${ }^{2}$}

\author{
${ }^{1}$ Katedra i Klinika Foniatrii i Audiologii Uniwersytetu \\ Medycznego w Poznaniu \\ ${ }^{2}$ Katedra i Zakład Informatyki i Statystyki Uniwersytetu \\ Medycznego w Poznaniu
}

Wstęp: Otoemisje akustyczne (OAEs), mimo stosunkowo krótkiego czasu, który minął od opisania samego zjawiska i opracowania metody ich rejestracji, są powszechnie stosowane w diagnostyce audiologicznej jako obiektywna i nieinwazyjna metoda badania komórek słuchowych zewnętrznych ślimaka. Obecnie otoemisje akustyczne są szeroko stosowane w badaniach klinicznych, jednak odmienne właściwości poszczególnych rodzajów OAEs każą zastanowić się nad wartością i interpretacją uzyskiwanych wyników.

Cel: Celem pracy była ocena występowania oraz wzajemne relacje 3 rodzajów OAEs (spontanicznej SOAE, wywołanej trzaskiem TEOAE, produktów zniekształceń ślimaka DPOAE) w zależności od średniego progu słuchowego obliczanego dla częstotliwości 0,$5 ; 1 ; 2 ; 4 \mathrm{kHz}$.

Materiał i metody: Badaniem objęto 141 osób w wieku 18-79: 40 - grupa kontrolna, 101 - pacjenci diagnozowani z powodu pogorszenia słuchu ze współistniejącymi lub nie szumami usznymi. U badanych wykonano przed pomiarem OAEs otoskopię, audiometrię tonalną i impedancyjną. Analizowano występowanie OAEs w badaniu przesiewowym wg zasady: OAEs obecne, brak rejestracji OAEs lub wynik wątpliwy w odniesieniu do DPOAE i TEOAE (ilość odpowiedzi pozytywnych do negatywnych 1:1). Wyniki: DPOAE były najczęściej rejestrowanymi otoemisjami $(86,25 \%$ w grupie kontrolnej i $61,25 \%$ w grupie badanej). Wyniki wątpliwe TEOAE i DPOAE stanowiły 6,25-23,75\% rejestrowanych wyników. Analizując współwstępowanie OAEs, stwierdzono zwiększenie odsetka niezgodnych wyników DPOAEs i TEOAEs wraz z narastaniem niedosłuchu. Stwierdzono różnice statystycznie istotne pomiędzy grupą kontrolną a grupą badaną z niedosłuchem powyżej $20 \mathrm{dBHL}$ oraz między tą ostatnią a grupą badaną z progiem słuchu do $20 \mathrm{dBHL}$ pod względem zgodności wyników DPOAEs i TEOAEs wszystkich trzech badanych otoemisji.

Wnioski: 1) DPOAE są najbardziej miarodajnym i jednoznacznym rodzajem otoemisji akustycznych wśród zastosowanych; ich wiarygodność rośnie w połączeniu z innymi rodzajami OAEs, zwłaszcza TEOAE. 2) Badanie pojedynczej OAE nie może być jedynym badaniem określającym stan czynnościowy komórek słuchowych zewnętrznych w uwagi na znaczący odsetek wyników wątpliwych i fałszywie ujemnych/dodatnich. 3) W badaniach za pomocą otoemisji akustycznych powinna obowiązywać zasada cross check.

\section{Zjawisko maskowania w warunkach dodatkowej stymulacji kontralateralnej}

\section{Andrzej Wicher \\ Instytut Akustyki Uniwersytetu im. Adama Mickiewicza w Poznaniu}

Selektywność częstotliwościowa słuchu, polegająca na zdolności do spostrzegania jednego dźwięku na tle innych, jest jedną z najistotniejszych cech funkcjonowania układu słuchowego. W ocenie selektywności częstotliwościowej wykorzystuje się zjawisko maskowania, które polega na wzroście progu słyszenia sygnału na tle dźwięku zakłócającego (maskera). Wzrost progu słyszenia wyrażany jest w decybelach i stanowi ilościową miarę zjawiska maskowania. Zjawisko maskowania wykorzystywane jest powszechnie w metodach diagnozowania słuchu, m.in. w audiometrii tonalnej, w celu maskowania międzyusznych przesłuchów, lub też w próbie nadprogowej Langenbecka. Sygnały maskujące stosuje się także w badaniach zrozumiałości mowy, prezentując dźwięki mowy na tle odpowiednio dobranego maskera.

Zjawisko maskowania wykorzystywane jest także w pomiarach Psychofizycznych Krzywych Strojenia (PTC). Zarejestrowane funkcje PTC umożliwiają także pomiar charakterystyk częstotliwościowych filtrów słuchowych. Przyjmuje się, że funkcjonowanie ucha wewnętrznego można opisać jako zbiór hipotetycznych, pasmowoprzepustowych filtrów, określanych mianem filtrów słuchowych. Wykorzystując zatem zjawisko maskowania, można dokonywać analizy selektywności częstotliwościowej słuchu, poprzez wyznaczenie charakterystyk częstotliwościowych filtrów słuchowych.

Tematyka referatu dotyczy wpływu stymulacji kontralateralnej na funkcje PTC oraz parametry filtrów słuchowych u osób ze słuchem prawidłowym. Należy podkreślić, że funkcjonowanie ślimaka ucha wewnętrznego może ulegać zmianom poprzez działanie eferentnej części układu słuchowego, której zasadniczą część stanowi układ oliwkowo-ślimakowy przyśrodkowy (MOC - medial olivocochlear system). Układ ten może wywoływać zmiany funkcjonowania ślimaka ucha wewnętrznego. Oddziaływanie to odzwierciedla się w zmianach parametrów funkcji 
PTC oraz charakterystykach częstotliwościowych filtrów słuchowych.

Badania wykonano $w$ ramach grantu NCN nr N N518 405438.

\section{Audiometria wysokich częstotliwości}

\section{Anna Furmann}

Instytut Akustyki Uniwersytetu im. Adama Mickiewicza w Poznaniu

Standardowo progi słyszalności wyznacza się w zakresie częstotliwości 125-8000 Hz.

Liczne badanie pokazują jednak, że prawidłowy słuch w zakresie tych częstotliwości nie zapewnia prawidłowego słuchu w zakresie częstotliwości większych, tzn. powyżej $8000 \mathrm{~Hz}$. Z drugiej strony badania pokazują, że aby poprawnie rozumieć mowę, szczególnie w okresie jej nauki, powinna ona do nas dochodzić w najszerszym zakresie częstotliwości. Dobre rozumienie mowy w zakresie częstotliwości 5-9 kHz gwarantuje dobry rozwój dziecka, zaś ubytki słyszenia w tym zakresie częstotliwości powodują złe rozumienie mowy zwłaszcza w hałasie.

Negatywny wpływ na stan słuchu w zakresie dużych częstotliwości mają takie choroby jak: cukrzyca, nadciśnienie tętnicze, niewydolność mięśnia sercowego, hiperlipidemia oraz oczywiście wiek osoby badanej. W przypadku dzieci wykazano, że na stan słuchu w zakresie wysokich częstotliwości wpływa między innymi: różyczka przebyta w życiu płodowym, obciążenia dziedziczne, przebyte zapalenie opon mózgowo-rdzeniowych, rozszczepy podniebienia, ale również, ze względu na przenikanie toksyn przez okienko okrągłe do ucha wewnętrznego, nawracające stany zapalne ucha środkowego. Badając tylko standardowe częstotliwości, nie jesteśmy wstanie tego wyłapać.

Zgłaszają się do nas osoby, które w zakresie standardowych częstotliwości mają słuch prawidłowy, ale mają problemy ze zrozumiałością mowy w hałasie. Może jest sens w ramach badań audiometrycznych wykonywać także badania $\mathrm{w}$ rozszerzonym górnym zakresie częstotliwości (8-16 kHz), wówczas byłaby większa szansa udzielenia odpowiedniej pomocy osobom z takimi ubytkami słuchu. W dobie współczesnych aparatów słuchowych z rozszerzonym pasmem przeniesienia (do $10 \mathrm{kHz}$ ) wydaje się to być możliwe.

W referacie zostaną przedstawione sposoby badania słuchu w zakresie wysokich częstotliwości oraz zostanie omówione, w jakich przypadkach należy stosować aparaty słuchowe o rozszerzonym paśmie przeniesienia.

\section{Bodźce nietonalne w badaniach audiologicznych}

\section{Bogna Małaczyńska, Piotr Świdziński}

Katedra i Klinika Foniatrii i Audiologii Uniwersytetu Medycznego im. K. Marcinkowskiego w Poznaniu

Celem pracy jest ocena zgodności wyników badań audiologicznych wykonywanych przy użyciu bodźców tonalnych z nietonalnymi takimi jak: trzask, logon, szum szeroko i wąskopasmowy, dźwięki mowy. W badaniach elektrofizjologicznych słuchu nie ma możliwości stymulowania narządu słuchu sygnałem ustalonym.

W pracy wykazano, że bodźce nietonalne stosowane w badaniach audiologicznych powinny być zdefiniowane przez parametry ich widma rzeczywistego. Zebrano wyniki badań audiometrycznych pacjentów i porównano je $\mathrm{z}$ analizami akustycznymi widm bodźców stosowanych w elektrofizjologii słuchu.

Należy być ostrożnym w interpretacji wyników tych badań. Odczucie głośności dźwięków złożonych zależy od typu bodźca i głębokości odbiorczego uszkodzenia słuchu.

\section{Pomiary in-situ}

\section{Artur Duraj, Roman Gołębiewski}

Instytut Akustyki Uniwersytetu im. Adama Mickiewicza w Poznaniu

Pomiary akustyczne w technice in-situ zyskują w ostatnich latach coraz większą popularność. Jest to możliwe przede wszystkim dzięki zmniejszeniu wymiarów sond mikrofonowych. Wyniki tych pomiarów są wymagane na etapie dopasowania aparatów słuchowych - szczególnie dzieciom. Wiąże się to $\mathrm{z}$ koniecznością uwzględnienia parametrów akustycznych zewnętrznego kanału słuchowego określonego parametrami RECD (Real-Ear-Coupler-Difference) oraz REUG (Real-Ear-Unaided-Gain). Pomiary in-situ pozwalają ponadto na uwzględnienie właściwości akustycznych wkładki usznej. Dodatkowo, pomiary in-situ są niezwykle przydatne do oceny efektywności zastosowanych w aparatach słuchowych systemów np. redukcji hałasu oraz sprzężenia zwrotnego. 


\section{Wartość diagnostyczna badań przesiewowych słuchu}

\section{Piotr Ŝwidziński}

Katedra i Klinika Foniatrii i Audiologii Uniwersytetu

Medycznego im. K. Marcinkowskiego w Poznaniu

Badanie przesiewowe słuchu powinno charakteryzować się dwoma podstawowymi cechami: musi być badaniem ściśle ograniczonym czasowo oraz wnosić jak najwięcej informacji o głębokości ubytku słuchu i miejscu jego uszkodzenia.

Celem pracy jest określenie optymalnego zestawu badań audiologicznych wykorzystywanych w badaniach przesiewowych słuchu. W pracy zaproponowano model praktycznego monitoringu ubytków słuchu w wieku od urodzenia do późnej starości.

$\mathrm{Na}$ etapie badań w wieku przedszkolnym sugeruje się stosowanie testów obiektywnych i metod orientacyjnych. W wieku szkolnym należy wykonać dokładną analizę skali i zakresu niedosłuchu, używając tak badań subiektywnych jak i obiektywnych. W wieku 18 do 60 lat skryning słuchowy powinien polegać na wykryciu wad nabytych i wykorzystywać badanie ankietowe i badanie audiometryczne w szerokim zakresie częstotliwości. Po 60 roku życia należy wprowadzić monitoring zmian w ubytkach słuchu spowodowanych starzeniem się a także wpływem chorób układowych, używając narzędzi niezbędnych w różnicowaniu szczególnie obwodowych i ośrodkowych uszkodzeń słuchu.
Małe uszy - poważne decyzje

\section{Maciej Maciągowski}

\section{Instytut Akustyki Uniwersytetu im. Adama Mickiewicza w Poznaniu}

W ciągu ostatnich kilkunastu lat, w wyniku powszechności przesiewowych badań noworodków, znacznie obniżył się wiek pacjentów, którym dopasowuje się aparaty słuchowe. Jest to grupa znacznie odmienna od dorosłych użytkowników aparatów słuchowych. Stąd istnieje potrzeba opracowania metod protezowania oraz aktualizacji technik weryfikacji dopasowania aparatu słuchowego. Wynika to $\mathrm{z}$ ograniczonej współpracy między protezowanym dzieckiem a zespołem specjalistów, a także z odmiennego niż u dorosłych trybu życia. Młodzi pacjenci wymagają większej słyszalności mowy w porównaniu z osobami dorosłymi i są mniej tolerancyjni na obecność hałasu i dźwięków o wysokim poziomie głośności.

Podczas procedury dopasowania aparatu najmłodszym pacjentom kluczowe, oprócz pomiaru RECD, jest ustalenie, czy obecność algorytmów stosowanych w aparacie (takich jak redukcja szumów, redukcja sprzężeń, adaptacyjna charakterystyka kierunkowa mikrofonu, kompresja czy transpozycja częstotliwości) nie ogranicza dostępu do sygnałów akustycznych potrzebnych do nauki języka. Zaawansowane funkcje aktywne w aparatach nie mogą pogarszać słyszalności mowy. Prawie wszystkie zostały opracowane z myślą o osobach dorosłych, nie można zakładać, że są one także odpowiednie dla dzieci. Aktualnie prowadzi się badania nad wpływem systemów redukcji hałasu, kierunkowości mikrofonów na zrozumiałość mowy i naukę słownictwa. Dopóki nie będą dostępne badania nad wpływem tych funkcji, adaptacyjne lub automatyczne funkcje u niemowląt i małych dzieci należy stosować ostrożnie ze względu na możliwość ograniczenia słyszalności sygnału mowy.

Celem weryfikacji dopasowania aparatu słuchowego jest ocena zrozumiałości mowy. Jeśli dziecko jest w stanie uczestniczyć w badaniach behawioralnych, test zrozumiałości mowy jest najbardziej prawidłową metodą oceny skuteczności dopasowania. Sam pomiar wzmocnienia nie pozwala ocenić funkcjonowania zaawansowanych funkcji, takich jak redukcja hałasu czy adaptacyjna charakterystyka kierunkowa. 